\title{
An Analysis of High School Students' Understanding and Reasoning of Average Concept
}

\author{
Özlem Engin ${ }^{a}$ and Alaattin Pusmaz \\ ${ }^{\mathbf{a}}$ Mathematics Teacher, Esenler Vocational Training Center, İstanbul/Turkey (ORCID: 0000-0002-2729-6986) \\ ${ }^{\mathbf{b}}$ Marmara University, Atatürk Faculty of Education, İstanbul/Turkey (ORCID: 0000-0003-4755-4089)
}

Article History: Received: 14 August 2020; Accepted: 2 January 2021; Published online: 3 February 2021

\begin{abstract}
The aim of this study is to identify high school students' understanding of average concept and the reasoning types they appeal to solve average problems. The case study approach was used in this study and the participants were selected by purposeful sampling. The participants consisted of five 9th grade and four 10th grade students, studying at a high school in Istanbul. In order to identify students' understanding of average, a test consisting of 5 open-ended problems were used and semi-structured interviews were held with each of the students. The data were analyzed by thematic analysis approach. For data analysis, framework proposed by Mokros and Russel (1995) was used to determine students' understanding of average and Lithner's (2008) framework was used to reveal their reasoning types. Results showed that students mostly understood average as mathematical point of balance. Creative mathematically founded reasoning and algorithmic reasoning was used the most. Creative reasoning is effective in reaching the right answer. In solutions where creative reasoning is used, students generally also have the idea of representativeness. The type of problem influences the reasoning process. Inadequacy of students' prior mathematics knowledge hinders both their understanding of the average and their reasoning skills.
\end{abstract}

Keywords: Average, mathematical reasoning, mathematics education

DOI: 10.16949 /turkbilmat.780680

\section{Introduction}

In today's world, students need to have reasoning skills to meet their future needs which will prepare them for future success as citizens and in the workplace, as well as enable them to pursue careers in mathematics and science (National Council of Teachers of Mathematics [NCTM], 2009). Mathematical literacy is one of the prerequisites regarding development and modernization of members of a country (Ersoy, 2003). Statistics knowledge, being a part of mathematical literacy, is used widely to interpret any kind of information, and people often see it in graphics, charts, averages (Toluk-Uçar \& Akdoğan, 2009). It is important to be competent to use statistics knowledge in a world changing and advancing rapidly.

Average is one of the basic concepts of statistics. Most students encounter this concept in daily life in forms such as height, age and score averages before receiving formal statistics training (Chatzivasileiou, Michalis \& Tsaliki, 2010). It is known that many years in math classes, average is taught limited to add and divide algorithm, which doesn't fully represent the context and lacks the relation with data (Turkey's Ministry of National Education [MoNE], 1998; Watson, Chick, \& Callingham, 2014; Watson \& Moritz, 2000). The increasing importance of statistical skills has been demonstrated by the emphasis on statistics in various mathematics education reform movements around the world. This leads a change in understanding of average concept in the curriculum of various countries (Australian Education Council, 1991; NCTM, 2000). Similarly, the average concept had been approached as calculations before 2006 in curriculum of Turkey (MoNE, 1998). Thereafter, in parallel with the developments in the world, mathematics curriculums have been changed to be related to real-life situations and to be conceptual rather than operational (MoNE, 2009, 2013, 2015, 2018a). According to the mathematics curriculum, 6th grade students are expected to use average to interpret and compare data related to the two data groups. In 7th grade, besides average concept, they are expected to recognize, calculate and interpret midpoint and mode concepts (MoNE, 2018a). In 9th grade, they are expected to associate the concepts average, midpoint and mode to the real-life situations (MoNE, 2018b).

Arithmetic average simply refers to the basic algorithm, that is to say, adding the value of each item in a group and dividing it by the total number of items in the group (Cai, 1998). This concept can be used to interpret a data of one group, or to compare two data groups by standard deviation (Cai, 2000; Mokros \& Russel, 1995). To comprehend the average, one needs to internalize thoroughly both average algorithm and the statistic relations of the term (Cai, 2000). Therefore, knowing the algorithm doesn't suffice to use arithmetic algorithm in different contexts, it requires conceptual comprehension. For this reason, in order to help students to develop accurate meaning, it is vital to know how they assign to a meaning to the average concept.

In their studies with 6th, 7th and 8th grade students, Mokros and Russel (1995) found that while solving the problems in different contexts, students' understandings of average were one of the five categories: average as

Corresponding Author: Alaattin Pusmaz iD email: apusmaz@marmara.edu.tr

Citation Information: Engin, Ö., \& Pusmaz, A. (2021). An analysis of high school students' understanding and reasoning of average concept. Turkish Journal of Computer and Mathematics Education, 12(1), 187-201. https://doi.org/10.16949/turkbilmat.780680 
mode, as algorithm, as reasonable, as midpoint and as mathematical point of balance. According to Mokros and Russel (1995, p. 26), students' understanding average as mode always use mode while interpreting data, they perceive mode as 'the most', they either barely use average algorithm or use it incorrectly. Students understanding average as algorithm, perceive it as using an algorithm that was learned in school, they confuse total, average and data concepts. Students understanding average as reasonable, consider average as a tool for making sense of the data. They choose an average that is representative of the data, both from a mathematical perspective and from a common-sense perspective. Students viewing average as midpoint, consider average as a tool for making sense of the data. They seem to believe the mean and middle are basically equivalent measures. Students perceiving average as mathematical point of balance consider average as a tool for making sense of the data. They look for a point of balance to represent the data, take into account the values of all the data points, they use the mean with a beginning understanding of the quantitative relationships among the data, total and average. They are able to work from a given average to data, from a given average to total, from a given total to data.

According to Mokros and Russel (1995) students who understand average as mode, are not able to recognize data as a whole, they perceive each data as a different value so that they cannot differentiate a value representing a group. Likewise, students who understand average as algorithm, cannot recognize the concept as a whole. Students who understand average as reasonable, middle point, and mathematical point of balance have not brought into dexterous solutions, yet they have been constructing the meaning of the concept.

In many studies, it is seen that although students know the arithmetic mean algorithm and use it in various situations, they do not fully understand its meaning (Cai, 2000; Konold \& Pollatsek, 2002; Mokros \& Russell 1995, Pollatsek, Lima, \& Well, 1981; Watson \& Moritz, 2000). Students who tend to use the algorithm in solving problems of average, cannot recognize average as representative of data (Toluk-Uçar \& Akdoğan, 2009). When the problem-solving strategies of students were examined, it was observed that they frequently understand average as mathematical point of balance and as algorithm (Enisoğlu \& Işıksal-Bostan, 2017). Although the students realize the representational power of the arithmetic mean, they have difficulty in evaluating the data as a whole (Chatzivasileiou et.al., 2010).

Besides student's understanding of arithmetic algorithm, the types of reasoning they use in problem solving worth researching. In addition to its significance in all disciplines, reasoning has special and essential place in mathematics (NCTM, 2009, p.4). In many countries, mathematical reasoning is valued and activities that improve mathematical reasoning are included in the mathematics curriculum (Fujita \& Jones, 2014; Herbert, Vale, Bragg, Loong \& Widjaja, 2015; Thompson, Hatfield, Yoon, Joshua \& Byerley,2017). Mathematical reasoning provides a strong foundation for students to understand a wide range of mathematical ideas such as rate of change and linearity, exponential growth, rate (Adu-Gyamfi \& Bossé, 2014; Ellis, Ozgur, Kulow, Dogan \& Amidon, 2016; Lobato \& Siebert, 2002). In other words, reasoning skills and understanding of math topics are closely linked.

Reasoning skill, which is very important for mathematics teaching (Kramarski, Mavarech, \& Lieberman, 2001), is described in the literature as a high-level skill that requires inference and judgement (Silver, 1997). Reasoning is a process of reaching a plausible conclusion by taking into account of all the elements and considering the sequences of thought (Umay, 2003). According to Lithner (2008), reasoning is the sequence of thinking adopted to produce assertions and reach conclusions in task solving.

Students often tend to use short-cut strategies by delaying interpretation when answering problems (Schoenfeld, 1991). Students who fail in reasoning use the knowledge rotely, their strategies do not depend on mathematical properties; even if they use the right mathematical calculations, these calculations mostly depend on algorithm, done by rotely (Lithner, 2000; 2003). The ones who have deficient reasoning do not complete the reasoning process, exhibit solutions lacking conceptual understanding, or bring imitative solutions (Umay \& Kaf, 2005). There are plenty of researches concerning students' reasoning process (Lithner, 2000; Bergqvist, Lithner, \& Sumpter, 2003; Bergqvist, Lithner, \& Sumpter, 2008; Erdem, 2011; Erdem \& Gürbüz, 2015; Poçan, Yaşaroğlu, \& İlhan, 2017; Umay \& Kaf, 2005). The results have shown that their level of reasoning is mediocre or low.

There are several approaches to evaluate the mathematical reasoning process (Farmaki \& Paschos, 2007; Fischbein, 1999; Lithner, 2008; Skemp, 1976; Wyndhamn \& Saljö, 1997). In this paper, Lithner's framework was adopted. This framework was chosen because it was created by examining the types of reasoning in many experimental studies (Lithner, 2000, 2003, 2004). According to Lithner (2008), the problem-solving process of the student proceeds as encountering the problem, choosing a strategy, applying the strategy, and obtaining a result and this process is seen as a product of his thinking method. Therefore, the students' reasoning is revealed based on their arguments. 
Lithner (2008) identifies two reasoning types: imitative reasoning (IR) and creative mathematically founded reasoning (CMR). Imitative reasoning is solving problems by using methods known or provided by someone else. This type of reasoning is separated into two: memorized reasoning (MR) and algorithmic reasoning (AR). The strategy used in MR is based on recalling. The person writes down the information by recalling. AR, on the other hand, is based on recalling the sequence of calculation rules, depending on the problem type. Since the calculation doesn't include any new piece, as long as the person doesn't make any careless mistakes, he or she gets the answer without reasoning (Boesen, Lithner, \& Palm, 2010). On the other hand, CMR can be described as problem solving, using mathematically established and internally structured claims. The distinctive characteristics of this strategy are originality, plausibility, and having a mathematical foundation (Lithner, 2008). Here, originality refers to being novel in reasoning sequence for the person who constructs it, plausibility refers to having plausible and correct explanations for strategies chosen or implemented, and finally having a mathematical foundation refers to not contradicting with the basic principles of mathematics in reasoning.

In the past years, many studies have been conducted that focus on primary and secondary school students' understanding of average, and the strategies they use in solving problems related to the average (Cai, 2000; Enisoğlu \& Işıksal-Bostan, 2017; Mokros \& Russell 1995; Toluk-Uçar \& Akdoğan, 2009; Watson \& Moritz, 2000). In these studies, it was noted that there were deficiencies in the students' knowledge of the average concept. Reasoning is especially important for understanding the connections and relationships between mathematical ideas (English, 1998). Examining students' deficiencies in understanding of average concept by focusing on their mathematical reasoning processes can help achieve more detailed results. Also, we do not have sufficient information about whether the above mentioned research results are valid for high school students. In this regard, in this study it was aimed to identify students' understanding of average concept and the reasoning types they appeal to solve average problems. As a result, answers to the following research questions were sought:

a. How do the 9th and 10th grade students understand the concept of average?

b. What are the reasoning types of 9th and 10th grade students when solving problems involving average concept?

\section{Method}

In this study, case study was used to determine students' understandings of average and the reasoning types they use while solving average problems. According to Merriam (2009) case study is an intensive, holistic description and analysis of a bounded phenomenon such as a program, an institution, a person, a process, or a social unit. Creswell and Poth (2018) describe the case study as a qualitative approach in which the investigator explores a real-life, a case or multiple cases over time, through detailed, in-depth data collection involving multiple sources of information. In this regard, the case which this study focuses on is, students' understandings of average and the reasoning types they use during average problem solving.

\subsection{Participants}

For determining the participants of this research, purposeful sampling, which is one of the criterion sampling methods, was used. The criterion sampling method is the selection of situations that meet some predetermined important criteria (Patton, 2002). The participants consisted of 9 students, 5 of whom were in the 9th grade and 4 of whom were in the 10th grade, studying at a high school in Istanbul. One of the 10th grade students was female (S10-2). Average is a subject of 9th grade at the high school level. For the participants, it has been deemed appropriate to select both the 9th grade students who have recently studied the subject and 10th grade students who have passed a certain period of time after the subject has been studied. The high school where the research was carried out is a public school with intermediate level students. The mathematics achievement level of the selected students is close to each other, being intermediate or lower which reflects the school achievement level. In selecting students, criteria such as mathematics grade point averages of medium and high levels according to school level, recommendations of teachers from different branches, their ability to express their thoughts clearly and their willingness to participate in the study were taken into consideration. In this study, concerning ethical principles, instead of their real names, S9-1, S9-2, S9-3, S9-4, S9-5 codes for 9th grade students and S10-1, S102, S10-3, S10-4 codes for 10th grade students were used.

\subsection{Data collection tools}

The data collection was conducted after the completion of basic statistics concepts namely; average, mode and median, which are $9^{\text {th }}$ grade topics. In order to identify students' understandings of average, a test consisting of 5 open ended problems (see Appendix) were used. An extensive literature review was made during the preparation of problems. The problems focused on the meaning of average concept, interpreting average-related expressions, calculating average. The first problem of the test was adapted from Gal, Rothschild, and Wagner (1990), the second was adapted from Watson and Moritz (2000), others were constructed by researchers, and the 
final form of the data collection tool was formed after obtaining expert opinion. Semi-structured interviews were conducted with students during the completion of the test. In this interview, problems were asked according to their responses, hereby it was aimed to identify their understandings of average and the reasoning types they use in the problem solving process. Examples of these questions are: "How did you do the solution?", "Can you explain the strategy you used?", "Why did you think so?", "What did you find?" and "Are you sure the solution is correct?"

\subsection{Data collection process}

The data for this research was collected in 2018. During data collection, semi-structured interviews were held with each of the students. Before the data collection, pilot study was carried out with a student who is appropriate for sampling criteria. In this way, it was aimed to take necessary measures for possible failures that may arise during the application process and the data collection process. The test, which consisted of 5 problems, was given to the student and asked to read the problems out loud and then solve them. This process was repeated individually with each student and this process, which had no time limit, was recorded with a video recorder. The researcher encouraged students to explain their solution strategies during the problem solving process. When their explanation was not clear enough, questions such as, "Why did you do this calculation? What is the reason for choosing these numbers? What did you take into consideration to do this?" were asked. Thus, students' understandings of average and their reasoning types were tried to be determined more clearly.

\subsection{Data Analysis}

For the analysis of the collected data, primarily video recordings were written, then the written responses to the open-ended problems and verbal explanations were analyzed by using Boyatzis' (1998) thematic analysis approach. The theme and codes to analyze the data were formed with the help of literature (theory-driven code development), subsequently the raw data was categorized by coding, the validity of the process was tried to be provided and the results were interpreted (Boyatzis, 1998).

In data analysis, in order to determine students' understandings of average and to reveal their reasoning types in problem solving, two different frameworks were used. First, students' understandings of average were determined using the framework proposed by Mokros and Russel (1995). Taking into consideration of the students' strategies and explanations, their understandings of average were coded as mode (M), algorithm (A), reasonable $(\mathrm{R})$, midpoint $(\mathrm{m})$, mathematical point of balance $(\mathrm{B})$. If the student interpreted the most repetitive data point as if it is average, the understanding of the student coded as $\mathrm{M}$. If the student used add-and-divide algorithm but he or she was not able to explain the relation between data and average, it was coded as A. If the student paid regard to the relevance of the result with the real-life experiences even though s/he used algorithm, if $\mathrm{s}$ /he considered the value the most proper among the various values, it was coded as R. if the student focused on the midpoint to make sense of the data and made interpretation with regard to be in the middle, it was coded as $\mathrm{m}$. If the student sought for a point of balance which represents the data and he or she can explain the relation between the obtained result and the data set, the understanding of the average was coded as B.

In addition to this, to reveal student's reasonings in each problem, Lithner's (2008) reasoning framework was used. In this study the reasoning types students use in problem solving were coded as MR, AR and CMR. The indicators of MR, AR and CMR are presented in Table 1. For determining the reasoning types of the students, it was taken into consideration whether these indicators were exhibited or not.

Table 1. Reasoning types

\begin{tabular}{|c|c|c|}
\hline Reasoning Types & Codes & Indicators \\
\hline & $\begin{array}{l}\text { Memorized } \\
\text { Reasoning } \\
(\mathrm{MR})\end{array}$ & $\begin{array}{l}\text { 1. The strategy choice is founded on recalling a complete answer. } \\
\text { 2. The strategy implementation consists only of writing it. }\end{array}$ \\
\hline $\begin{array}{l}\text { Imitative } \\
\text { Reasoning (IR) }\end{array}$ & $\begin{array}{l}\text { Algorithmic } \\
\text { Reasoning } \\
\text { (AR) }\end{array}$ & $\begin{array}{l}\text { 1. The strategy choice is to recall a solution algorithm. The } \\
\text { predictive argumentation may be of different kinds, but there is no } \\
\text { need to create a new solution. } \\
\text { 2. The remaining reasoning parts of the strategy implementation } \\
\text { are trivial for the reasoner, only a careless mistake can prevent an } \\
\text { answer from being reached }\end{array}$ \\
\hline $\begin{array}{l}\text { Creative mathematical } \\
\text { founded reasoning (CMR) }\end{array}$ & (CMR) & $\begin{array}{l}\text { 1.Novelty: The reasoner creates a new set of judgments or } \\
\text { recreates the forgotten one. } \\
\text { 2. Reasonability: There are arguments that explain why the results } \\
\text { that support strategy selection and/or strategy implementation are } \\
\text { true or plausible. } \\
\text { 3. Mathematical foundation: Arguments are related with the } \\
\text { mathematical properties of the components involved in the } \\
\text { reasoning. }\end{array}$ \\
\hline
\end{tabular}


For the reliability of coding, approximately $10 \%$ of the data is coded separately by the authors. As a result of coding, over $85 \%$ of consistency was observed. It is recommended that the agreement between encoders is higher than $80 \%$ (Miles \& Huberman, 1994). Then, the situations in which different codings were made were examined one by one and negotiated until a compromise was reached. An expert opinion was consulted on these data coding and the ultimate form of the coding was given. Finally, the coding process was completed.

\section{Findings}

In this section, findings related to students' understanding of average and their reasoning types on problem solving are presented below two headings.

\subsection{Students' Understanding of Average}

The framework provided by Mokros \& Russel (1995) was used in order to determine students' understanding of average. As a result of the analysis of the data, it was seen that the students attributed different meanings to the average concept in different problems. Table 2 presents students' frequencies of understandings of average concept in problem solving. They understand average as a mathematical point of balance mostly. Although this approach is mostly used by the S9-3 and S9-4, it was used by a total of six students. Reasonable value, algorithm, and midpoint follow it, respectively. Only one student understood average as mode.

Table 2. Students' different understandings of average

\begin{tabular}{|c|c|c|c|c|c|}
\hline & \multicolumn{5}{|c|}{ Understandings of Average } \\
\hline & Mode $(M)$ & Algorithm (A) & $\begin{array}{c}\text { Reasonable } \\
(R)\end{array}$ & Midpoint (m) & $\begin{array}{c}\text { Mathematical } \\
\text { point of } \\
\text { belance }(B)\end{array}$ \\
\hline Frequencies of codes & 1 & 11 & 13 & 7 & 18 \\
\hline $\begin{array}{l}\text { Frequencies of } \\
\text { participants }\end{array}$ & 1 & 5 & 7 & 5 & 6 \\
\hline
\end{tabular}

In Table 3, students' understandings of average for each problem can be observed. Since students' understandings of average in solving and interpreting the solution differed in the 4th problem, the coding was made separately for these two cases. In Table 3, the students' understandings of average when solving the problem is coded by (i) and when interpreting the problem is coded (ii). Moreover, some students left several problems unanswered and the "-" symbol is used in the table for this situation.

Table 3. Students' understandings of average on each problem

\begin{tabular}{|c|c|c|c|c|c|c|c|c|c|}
\hline Problems & S9-1 & S9-2 & $59-3$ & $59-4$ & S9-5 & S10-1 & S10-2 & S10-3 & $S 10-4$ \\
\hline 1 & $\mathrm{~m}$ & M & B & B & $\mathrm{R}$ & $\mathrm{R}$ & $\mathrm{R}$ & $\mathrm{R}$ & $\mathrm{R}$ \\
\hline 2 & $\mathrm{~A}$ & - & $\mathrm{B}$ & $\mathrm{B}$ & $\mathrm{A}$ & $\mathrm{A}$ & $\mathrm{A}$ & $\mathrm{A}$ & - \\
\hline 3 & $\mathrm{~B}$ & $\mathrm{R}$ & $\mathrm{B}$ & B & A & $\mathrm{A}$ & $\mathrm{B}$ & $\mathrm{B}$ & $\mathrm{R}$ \\
\hline 4 (i) & $\mathrm{m}$ & $\mathrm{m}$ & B & $\mathrm{R}$ & $\mathrm{A}$ & B & B & $\mathrm{m}$ & $\mathrm{m}$ \\
\hline 4 (ii) & $\mathrm{A}$ & $\mathrm{m}$ & $\mathrm{B}$ & $\mathrm{R}$ & $\mathrm{R}$ & $\mathrm{R}$ & $\mathrm{R}$ & $\mathrm{A}$ & $\mathrm{R}$ \\
\hline 5 & B & - & B & B & A & $\mathrm{m}$ & B & B & - \\
\hline
\end{tabular}

In the analysis of the data, it was observed that students could interpret average differently for any problem. For instance, in the first problem students' understandings of average appeared in four different categories: midpoint, mode, mathematical point of balance, reasonable value. In some cases, students could not answer the problem and passed it. Except for S9-3 who considered average in the same meaning in every problem, students exhibited different understandings in different problems. As an example of this, the dialogues showing the approach of S9-5 to question 1 and question 5 can be examined. The dialogue between S9-5 and the researcher in problem 1 is as follows:

The researcher: So how many students can be in a class in this case, can you give an example?

S9-5: In a classroom... 30 ..35

The researcher: It doesn't have to be 32 then. Could it be 50-60?

S9-5 It may be 50-60 but 50 is appropriate at most

The researcher: Is there a limit to this?

S9-5 There is. It can't be 60-70-80

The researcher: Why not?

S9-5: It (the class) gets very crowded .. it would be noisy.

The researcher: I'm asking regarding as a number. Let's say there are 100 people in a class.

Could the average of all classes be 32?

S9-5: No way. There should be something close to 32 
S9-5 evaluated the meaning of the mean given in the 1st problem by using real life experiences, stated that a class could not be too crowded, and also stated that when an average of 32 is given, the number of students in other classes should be close to this value. Accordingly, the student's answer was coded as R. On the other hand, the same student estimated values of lengths of the sticks in the fifth problem. Then, he tried to find a result by adding and dividing these estimated values. S9-5 insistently tried to use the algorithm which he knew. This indicates he considered average as algorithm in the fifth problem.

Evaluation was made according to students' predominant approach summarizing the data in each problem. It was seen that average was considered as reasonable in the first, as algorithm in the second, as mathematical point of balance in the third, as reasonable value in the fourth, as mathematical point of balance in the fifth problem. While giving examples of average in the first problem, students generally appealed examples based on their school life such as "grade-point average, average of exams, average of school report, mathematics". Interpreting the expression "32 students on average" and evaluating its plausibility, they appealed real-life experiences. Students mostly believe that the average is a value (estimation) that can have one of several values. Furthermore, they consider the average as "close, around, near."

The following dialogues demonstrate how students rely on "close near, around" ideas. It was seen that these students perceived average as reasonable. The dialogue between the researcher and S10-2 about the first prblem is as follows:

S10-2: There are 32 students in each class

The researcher: There are 32 students in each class for sure?

S10-2: No, it's average, it's around.

The dialogue between the researcher and S10-1 about the first prblem is as follows:

S10-1: So there were 32 students. So the average is 32. So it could be more than 32, it could be less.

The researcher: Well, you said it could be more than 32. Could it be too much? For example, can it be 60 ?

S10-1: No it can't be that much.

The researcher: How many can it be?

S10-1: May be 40-42.

The researcher: Can it be too little?

S10-1: It can't be too little. Because you know what he says it is average ... it must be close. It shouldn't be too much.

In the second problem, students predominantly did calculations (adding and dividing) with given numbers to reach a result. These students considered finding average as implementing the learned algorithm. In the students' wrong answer of this problem, they tried to use average algorithm mostly with useless and cyclical methods. Figure 1a demonstrates S10-2's, and Figure 1b demonstrates S10-3's calculations while solving the problem.
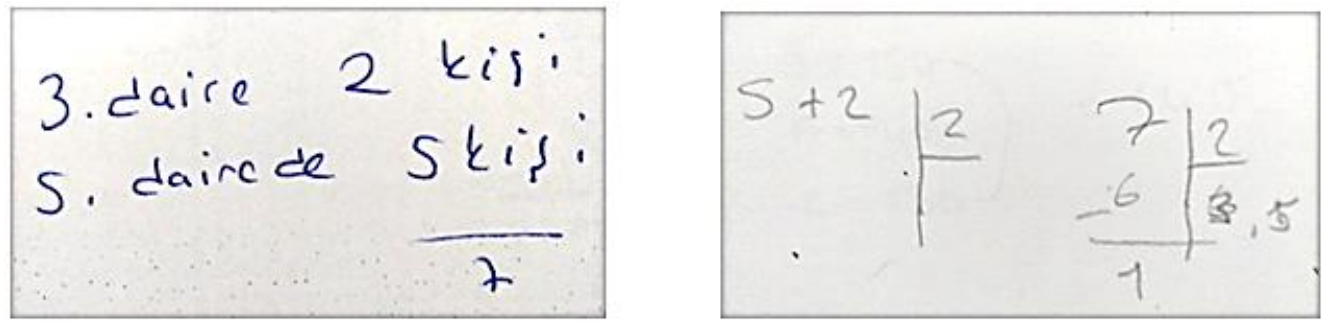

a.S10-2's Calculation (3. household 2 people, 5. household 5 people) b. S10-3's Calculation

Figure 1. Examples of students' answers for the second problem

The dialogue between the researcher and S10-2 during the solution of second problem shown in Figure 1a is as follows:

S10-2: There were 2 people in 3rd household, 5people in 5th.. How many people are in 8 flats? If there are 10 households... (he rereads the question and pauses.) Since this place turns out to be $7 \ldots$ (calcuating $5+2$ ) in 8 households... (thinks for a while) It's wrong (he abandons the solution)

The dialogue between the researcher and S10-3 during the solution of second problem shown in Figure 1b is as follows:

The researcher: Why did you add 5 and 2? What did you find when you gathered (found 7:2 = $3,5)$.

S10-3: Average 
The researcher: The average of what?

S10-3: In two households.

The researcher: How did you plan to use it?

S10-3: Multiply this by 8

The researcher: Why

S10-3: make 3,6 ... because it says 3,6... (Trying to make the result 3.6)

The researcher: How will you do that? (After a few more adding and dividing attempts, he erases and abandons the solution)

It is seen that these students abandoned the solution, not being sure whether the solution would be correct or not. However they both tried to add and divide the given numbers. This indicates they consider average as an algorithm.In the third problem, when the students were creating the team that met the conditions, it was seen that they first chose three people and calculated their height averages, if they could not reach an appropriate result, they tended to choose another triple. While some students randomized these trials, some students sought other lengths to balance their chosen length to an average. For instance, while trying to reach an average between 138 $\mathrm{cm}$ and $145 \mathrm{~cm}, \mathrm{~S} 9-1$ and the researcher had the following dialogue:

S9-1: Let's try (trying to create the team, he writes Ceren 130, Furat 180, Demet 120)

The researcher: Why did you choose those ones?

S9-1: Since Firat is $180 \mathrm{~cm}$, I should have chosen the two others short ones (Calculates the average height of 3 people as 143,..) This (team) is possible.

It is seen that these students, who try to balance by taking into account all the data, perceived average as mathematical point of balance. Four students, instead of making calculations, made sure to choose the length of the students to be included in the team, close to the desired range in the problem. S9-2 began choosing Ayça, the only appropriate for the requested average of the team. When S9-2 was reminded that the team should involve three people, added the others. It was seen that these students interpreted the average mathematically as "around", that is, as reasonable. S10-4 made the following explanation while solving this problem:

The researcher: Did you understand (the question)?

S10-4: Yes. (thinking) Ceren?

The researcher: Ceren?

S10-4: No, sorry not Ceren. There is Ayça.

The researcher: Ayça .. yes?

S10-4: Could it be Burak?

The researcher: I don't know. You know which 3 people you choose. Then you will explain to me why.

S10-4: (silence, just looking, not writing) Ayça, Burak and Furat

The researcher: Why?

S10-4: He doesn't say anything for sure, either. Maybe longer ones can also join (the team). But since he says 138 (pointing at Ceren-130) this little one cannot join. But over 145 (those) maybe can join.

It is noteworthy that this student's tendency to round up the large values as well as taking the close values. This situation was also seen in other students in the fourth problem.

None of the students were able to solve the fourth problem completely correctly. While finding the average, S9-2 chose the middle of the graph, others summed up the values of the columns and divided the result by 4 . In the same problem, some students determined a correct place while drawing a column, yet they tried to match their length to a length between the left and right column of the place where he was drawing. It might be argued that some of these students could find correct results if they could read the graph accurately.

For example, S9-4 misinterpreted the graph: "In the second packet... There are 10. In the third packet, there are 20 , in the fourth packet there are $15 \ldots 75$ in total." Although he placed the column in the right place when he was going to draw a new column, he draws the column 5 units long, on the grounds that it was the 5 th packet. In other words, the student actually performed consistent operations within the graphic interpreting system he created. But this led him to a wrong answer.

Another remarkable point in the fourth problem is that after finding the average number of sugars in a group of packets, S9-5 and S10-2 argued that all sugar packets should contain at least as much sugar as the average number of sugars. For instance, after finding the average with 75:4=18 calculation, S9-5 explained about the number of sugars that packets may contain: “... Because it has the denominator. (he actually refers to the remainder of the division) (The number of sugars that can come out of the packets) can be above 18 but not less. It could be 19 or 20, but not 17." S9-5 and similarly S10-2 considered the average they calculated as a lower bound. 
In the fifth problem, most of the students considered average as mathematical point of balance. Students who perceived average as mathematical point of balance initially tried to obtain the total length of the sticks, by placing the auxiliary sticks given to them end-to-end or by measuring them repeatedly. In this problem, two of the students could not provide a solution, one of them tried to reach the conclusion by assigning estimated length values to the sticks and making calculations with the assigned values (algorithm)

Another student focused on finding a length that would fit in the middle by placing three sticks side by side (midpoint). S10-1 was seeking for a length that would be in the middle of the given sticks' lengths, therefore he understood average as midpoint. After hearing the question put three of the sticks next to each other, not end to end and he had the following dialogue with the researcher:

S10-1: It (the result) will not be smaller than this (showing the smallest stick) nor will it be taller than this (showing the longest stick).

The researcher: So how long will it be compared to this one? (showing the medium stick)

S10-1: It will be a little longer than that..

The researcher: How did you decide it is longer than that?

S10-1: Because the long one is too long. But the medium one is closer to the small one. So this will get a little bigger (medium one). (then he takes this medium stick and takes it next to other rod groups and measures it)

The researcher: Are you looking for something close to that one?

S10-1: Close to it, a little big, not too big. (Finally he decides to choose the blue stick).

\subsection{Students' Reasoning Types on Problem Solving}

Lithner's (2008) framework was used to reveal students' reasoning types. When student's reasoning types were scrutinized, it was observed that they tended to use different forms of reasoning in different problems. As can be seen in Table 4, which demonstrates the frequencies of students' reasoning types, the most used reasoning type was CMR followed by AR and MR.

Table 4. Students' reasoning types

\begin{tabular}{ccc}
$\begin{array}{c}\text { Memorized Reasoning } \\
(\text { MR })\end{array}$ & $\begin{array}{c}\text { Algorithmic Reasoning } \\
(\boldsymbol{A R})\end{array}$ & $\begin{array}{c}\text { Creative Mathematically } \\
\text { Founded Reasoning } \\
(\text { CMR })\end{array}$ \\
\hline 12 & 14 & 15
\end{tabular}

Frequencies

0-4) could not

In Table 5, students' reasoning types in each problem can be seen. Two students (S9-2, S10-4) could
swer the second and fifth problems. Students usually used similar reasoning types in the same problems.

In the first problem, all the students made similar interpretations reminding the average algorithm they had learned before. For instance, while explaining how the average is founded, S9-1: "He might have summed the numbers of students and be divided it into the number of the classrooms.", S10-4 "All the students were added and were divided into the (total) number of the classrooms."

Table 5. Students' reasoning types on problem solving

\begin{tabular}{llllllllll}
\hline Problems & $\mathbf{S 9 - 1}$ & $\mathbf{S 9 - 2}$ & $\mathbf{S 9 - 3}$ & $\mathbf{S 9 - 4}$ & $\mathbf{S 9 - 5}$ & $\mathbf{S 1 0 - 1}$ & $\mathbf{S 1 0 - 2}$ & $\boldsymbol{S 1 0 - 3}$ & $\boldsymbol{S 1 0 - 4}$ \\
\hline $\begin{array}{l}\text { 1st } \\
\text { problem }\end{array}$ & MR & MR & MR & MR & MR & MR & MR & MR & MR \\
\hline $\begin{array}{l}\text { 2nd } \\
\text { problem }\end{array}$ & AR & - & CMR & CMR & AR & AR & CMR & AR & - \\
\hline $\begin{array}{l}\text { 3rd } \\
\text { problem }\end{array}$ & CMR & MR & CMR & CMR & AR & CMR & CMR & CMR & MR \\
\hline $\begin{array}{l}\text { 4th } \\
\text { problem }\end{array}$ & AR & MR & AR & AR & AR & AR & AR & AR & AR \\
\hline $\begin{array}{l}\text { th } \\
\text { problem }\end{array}$ & CMR & - & CMR & CMR & AR & CMR & CMR & CMR & - \\
\hline
\end{tabular}

In the $\mathrm{b}$ subproblem of the second problem, while four students used AR, three students used CMR. In the second problem, S9-3 could not first understand the number of people per household in the problem being 3.6. This is a sign that the problem is out of routine for him. Then, when asked to calculate how many people were in the remaining 8 households, the following dialogue was with the researcher:

S9-3: 3,6 multiplied (by 10), then it equals 36.

The researcher: What does that number refer to?

S9-3: The number of people in the apartment. Here 2, there 5, totally 7 people. How many left... 29

people. Ah, there is a remainder. (tried to calculate a division) 
The researcher: Well, what did you find?

S9-3: There are 29 people in the 8 houses. Let me delete this, this was unnecessary (noticing his mistake, he erased the division operation) Done.

S9-3 made a reasonable and mathematically founded beginning and attempted to use average algorithm afterward. However, he then realized his mistake and corrected. The reasoning type of the student was considered as CMR.

In the third problem, students mostly used CMR. Apart from them, the two of the other three used MR, one used the AR. For example, S9-5 had difficulties to appoint the students in the team and did not do any calculation for a while. When asked how he could calculate this, he chose three people for the basketball team and obtained 420 by adding their heights. After, the student wrote " $410 / 3$ " then, asked "The average of all these students, isn't it? The three of them?" S9-5 tried to use the average algorithm, nevertheless, he did not make a proper decision for a solution. He could not decide which students to choose for the team. His solution and the decisions in the process demonstrated the use of AR.

Whilst a student used MR in the fourth problem, the other used AR. S9-2 who did MR, said the following when calculating the average:

\section{S9-2: Is it (the solution) something around 17,5?}

The researcher: Can you tell me how did you do it?

S9-2: This, something between these. (pointing to the numbers 15 and 20 on the horizontal axis of the graph)

In this case, the student focused on the four columns standing side by side on the graph and their positions. He believes that the value in the middle of the four columns is average. He acted upon his memorized knowledge based on the idea that the average is in the middle, did not make any calculations or produce a new argument.

In the fifth problem, all the students found the problem unusual. Whereas two of the students could not reach any solution, all the students who used CMR reached the correct result by measuring sticks repetitively or adding them end to end and they offered reasonable mathematically founded arguments. S9-4 who used creative CMR lined the sticks end to end and said: "It will be divided by 3, so that we need to find a stick which is one-third of this (total length)." S9-4 said, "We cannot be sure (of the answer)" at first but immediately after said: "We can actually be.". The student reached the correct answer by making triple measurements with the black, blue and red sticks given. His initial hesitation demonstrates the novelty of the situation.

In the fifth problem, S9-5 estimated the lengths in order to use the algorithm he recalled and tried to find a solution by adding and dividing these estimated lengths. This student wrote " $7,5+4+3=13,5$ " on paper to solve the problem. Thereafter, the dialogue between the student and the researcher was as follows:

The researcher: What are you adding?

S9-5: The measures.

The researcher: How did you measure?

S9-5: The two seems ... cm to me (implying his guess) (He did some calculations to solve and chose the red stick.)

The researcher: Why?

S9-5: Because it seems $4 \mathrm{~cm}$ to me. The average is $4 \mathrm{~cm}$, too. The nearest value is the red one. If this is 4 , then the red is probably 4,5.)

It was seen that the students was relying on the average algorithm even if there was no lengths given. As a result, this problem was coded as AR for S9-5.

To address the relation between students' understanding of average and their reasoning types, the data were analyzed further. It was seen that majority of students were not able to answer most of the problems. Therefore, it was observed that students generally failed to solve problems. Besides, in solutions where CMR was used, students generally also had the idea of representativeness. It has been observed that students' lack of prior knowledge is a preventive factor both in reasoning processes and in understanding the average concept.

\section{Conclusion and Discussion}

In this study, it was observed that students mostly considered average as mathematical point of balance. While two students (S9-3 and S9-4) understood the average as the mathematical balance point in most problems, there were four more students who had this understanding as well. Besides, average as reasonable and as algorithm approaches were also seen. Conspicuously, only one student (S9-3) considered average as mathematical point of balance in all problems and was the only one student who answered all the problems correctly. The $9^{\text {th }}$ and $10^{\text {th }}$ grade students in the study group learned the themes related to the average concept in secondary school and in the $9^{\text {th }}$ grade. Therefore, students are expected to have fully acquired the concept of 
average at this grade level. However, the majority of students were able to answer half or less of the given problems. This shows their lack of knowledge on the average concept.

According to Mokros and Russel (1995), it is necessary to perceive the understanding of average and its different meanings in the form of median and mode in order to form an opinion about its representativeness of the data. Whereas students who rely on the mode and algorithm are not aware that the average as being representative of the data set as a whole; students with reasonable, middle point, mathematical point of balance approaches realize its representativeness of the data set (Mokros \& Russel, 1995).

S9-3 solving all the problems correctly, considered average as balance, S9-4 solving four problems correctly considered average as reasonable and balance. It can be deduced that these two students are better at apprehending the role of average of being representative of the data. Other students used average as mode and/or algorithm in particular problems. This may indicate most of the students could not construct the representativeness of the average yet, or they are on constructing process. A similar situation has been observed in pre-secondary students (Toluk-Uçar \& Akdoğan, 2009). This may indicate that students retain the information they conceptualized in their secondary school years, also during their high school years. Since the time devoted to the concept of average and the way subjects are taught while studying topics at high school level assumes that students have learned the subject in secondary school, the problems that exist in secondary school seem to be continued in high school.

As a result of this research, it was revealed that students mostly consider average as mathematical point of balance. In some studies, it has been concluded that the students mostly consider average as algorithm (Enisoğlu \& Işıksal-Bostan, 2017; Mokros \& Russel,1995; Toluk- Uçar \& Akdoğan, 2009). The possible reason of this difference in results is aforementioned studies were conducted with primary school students even though this study was conducted with $9^{\text {th }}$ and $10^{\text {th }}$ grade students. Because the understanding of the representativeness of average increases as the grade level increases (Mokros \& Russel, 1995; Toluk- Uçar \& Akdoğan, 2009). Nonetheless, students predominantly considered average as algorithm after mathematical point of balance and reasonable.

The examples students gave for the first problem were usually about the algorithm they used in calculating their grade point averages. Cai (1998) stated that students generally tend to use the add-and-divide algorithm in problem solving, but most of them fail to implement the algorithm. This study revealed that students mostly think that the values in a data group should be close to the average. Students who think that the values might be far from the average, and that if a value is far from the average, there may be another value that balances it, were better at taking flexible and successful approaches to problem solving. It is an expected result that students with mathematical point of balance approach are better than the students with algorithmic approach in working on the problem more flexible due to recognizing the representativeness of average of the data (Mokros \& Russel, 1995).

Another obstacle that limits students' understandings of average is their deficiencies with the prior knowledge such as reading the chart incorrectly. Especially, in the fourth problem, owing to their lack of knowledge in interpreting graphs, students had difficulties to interpret the data and used the data incorrectly. Students' difficulties in interpreting the graphs in Turkey is known (Toluk-Uçar \& Akdoğan, 2009; Güler, 2013). Moreover, in both fourth and fifth problems, students concluded that other data should be larger than the average when they obtained the remainder result during the division operation in the average algorithm. This is a situation that is caused by their misuse of a fact they remember from the division algorithm, in other words, they show the lack of math preliminary information and limit them when interpreting the mean. The insufficient level of readiness of secondary school students is one of the main reasons for having difficulties in mathematics lessons (Dane, Kudu, \& Balkı, 2009; Gürbüz, Toprak, Yapıc1, \& Doğan, 2011).

Students' dispositions of making similar interpretations on the same problems may indicate that the context of the problem led them to think alike. The probable reason for this may be that students do not have the prior knowledge of mathematics required by the context of the problem, rather than being unfamiliar to problems in different contexts. For instance, in the fifth problem which has different context but does not require prior arithmetic knowledge, students tended to apply solutions reflecting the understanding of balance, and they solved it correctly. Besides, in a larger extent, students had other approaches reflecting their apprehension of average as being representative of the data rather than considering it as mode or algorithm. Hence, one of the distinctive results of this study is, even if the understanding of average is on a higher level, lack of prior mathematical knowledge hinders students from solving the problems correctly.

When the types of reasoning students used in problem solving were examined, it was seen that they used different types of reasoning in different problems. AR was used the most, but some students were unable to reason and did not want to solve the problem. Students S9-3 and S9-4 with the most correct answers used CMR most, in other words students using CMR mostly were the most successful problem-solvers. 
The mathematical structure of students' arguments in problem solving shapes their reasoning types. While it is possible for the student to reach the answer to a routine problem by applying certain algorithms, it is necessary to develop different perspectives in a non-routine problem. Boesen, Lithner, and Palm (2010) state that students use IR when they encounter familiar problems usually by recalling algorithms and formulas. In the first problem, all the students used MR because this problem only requires recalling the information they had learned before, and it was a routine, verbal problem. Third and the proceeding problems were non-routine for the students. The type of reasoning used in the third and fifth problems was mostly CMR. In the fourth problem students applied $\mathrm{AR}$ and most of them answered incorrectly. The main reason of this is the deficiencies in their conceptual knowledge such as interpreting the change in the average. The fact that lack of conceptual information negatively affects mathematical reasoning processes is a situation encountered in the literature (Bergqvist et al., 2003; Umay \& Kaf, 2005; Yeşildere \& Türnüklü, 2007).

Twelve of the fifteen solutions which CMR was used as a reasoning type, led students to the correct answer. Only four of the other reasoning types led them to correct answers. This shows us that CMR is effective in reaching the right answer. Furthermore, twelve of these fifteen solutions which CMR was used, students considered average as mathematical point of balance, one of them as middle point, and two of them as algorithm. Mokros and Russel (1995) explained that students who consider average as reasonable, middle point and mathematical point of balance understand the representativeness of average. The results show that in cases where reasoning is high, that is, in solutions where CMR is used, students generally also have the idea of representativeness.

Besides, AR was used in nine of the student solutions approaching the average as an algorithm and CMR was used in two of them. This signifies students interpreting average as implementing add-and-divide procedure tend to use AR, that is, they tend to recall certain calculation rules in order, depending on the problem type. Moreover, students making AR mostly could not reach a correct answer and they did not tend to change their solution strategies. This is possibly because of the difficulties in understanding the problem and not recognizing whether their strategy is appropriate or not. Bergqvist, Lithner, and Sumpter (2008) stated that high school students who have similar traits with this study generally use AR in problem solving and when they cannot a reach an answer, they barely focus on why the algorithm did not work or whether it can be altered according to the problem.

Students' understandings of average and their reasoning types were centered on several categories as mentioned above. This demonstrates the type of problem influence the reasoning process. Boesen et al. (2010) also stated students' reasoning types depend on the reasoning type required by the given task. Therefore, students may need to be introduced to different types of problems at the appropriate time and sequence in order to improve their reasoning.

Two students did not answer some problems. Nevertheless, it can be inferred from the first problem that they at least know the average algorithm. However, they did not attempt to solve the problem and did not develop any novel point of view. Umay and Kaf (2005) reported that students are nervous and unsuccessful in using reasoning in unfamiliar problems and that it is necessary to introduce non-routine problems at schools. Jonsson, Norqvist, Liljekvist, and Lithner (2014) stated CMR is favored to improve students' reasoning skills and offered to create learning environments that lead students to think in different situations. The crucial point is not to put overwhelming barriers while encouraging them to learn. These learning environments should give students opportunities to express and discuss their ideas (Bergqvist \& Lithner, 2012).

As a result, more research is needed to understand the thinking processes related to the average concept of students. It seems that courses that focus on algorithmic processes do not help to fully understand this concept. It is important to create suitable learning environments for students who do not fully understand the power of the average to represent the data and understand average as mode or algorithm. Also, in such a learning environment, it may be beneficial to use daily life problems instead of fictional questions and to effectively address mathematical reasoning in solving them. Researches to be conducted in learning environments designed in this way may allow us to understand the changes in students' understanding of the power of the average to represent the data as well as their reasoning process.

\section{References}

Adu-Gyamfi, K., \& Bossé, M. J. (2014). Processes and reasoning in representations of linear functions. International Journal of Science and Mathematics Education, 12(1), 167-192.

Australian Education Council. (1991). A national statement on mathematics for Australian schools. Carlton, VIC: Australian Education Council.

Bergqvist, T., \& Lithner, J. (2012). Mathematical reasoning in teachers' presentations. The Journal of Mathematical Behavior, 31(2), 252-269. 
Bergqvist, T., Lithner, J., \& Sumpter, L. (2003). Reasoning characteristics in upper secondary school students' task solving. Department of Mathematics and Mathematical Statistics, Umeå University, Research Reports in Mathematics Education (1).

Bergqvist, T., Lithner, J., \& Sumpter, L. (2008). Upper secondary students' task reasoning. International Journal of Mathematical Education in Science and Technology, 39(1), 1-12.

Boesen, J., Lithner, J., \& Palm, T. (2010). The relation between types of assessment tasks and the mathematical reasoning students use. Educational Studies in Mathematics, 75(1), 89-105.

Boyatzis, R. E. (1998). Transforming qualitative information: Thematic analysis and code development. Thousand Oaks: Sage Publications.

Cai, J. (1998). Exploring students' conceptual understanding of the averaging algorithm. School Science and Mathematics, 98(2), 93-98.

Cai, J. (2000). Understanding and representing the arithmetic averaging algorithm: An analysis and comparison of us and Chinese students' responses, International Journal of Mathematical Education in Science and Technology, 31, 839-855.

Chatzivasileiou, E., Michalis, I., \& Tsaliki, C. (2010). Elementary school students' understanding of concept of arithmetic mean. In C. Reading (Ed.), Data and context in statistics education: Towards an evidence based society. Proceedings of the Eighth International Conference on Teaching Statistics. The Netherlands: International Statistical Institute.

Creswell, J. W., \& Poth, C. N. (2018). Qualitative inquiry and research design: Choosing among five approaches (Fourth ed.). Thousand Oaks: Sage Publications.

Dane, A., Kudu, M., \& Balkı, N. (2009). The factors negatıvely effectıng high school students' mathematical success according to their perceptions. Erzincan University Journal of Science and Technology, 2(1), 17-34.

Ellis, A. B., Ozgur, Z., Kulow, T., Dogan, M. F., \& Amidon, J. (2016). An exponential growth learning trajectory: Students' emerging understanding of exponential growth through covariation. Mathematical Thinking and Learning, 18(3), 151-181.

English, L. D. (1998). Editorial Mathematical Reasoning: Nature, Form, and Development. Mathematical Cognition, 4(2), 81-83. doi:10.1080/135467998387334.

Enisoglu, D., \& Isiksal-Bostan, M. (2017). Identifying students'possible solution strategies while solving questions regarding the concept of mean. The Eurasia Proceedings of Educational and Social Sciences, 6, 24-30.

Erdem, E. (2011). An investigation of the seventh grade students' mathematical and probabilistic reasoning skills. (Unpublished master dissertation, Adiyaman University). Retrieved from https://tez.yok.gov.tr/UlusalTezMerkezi/

Erdem, E., \& Gürbüz, R. (2015). An analysis of seventh-grade students'mathematical reasoning. Cukurova University Faculty of Education Journal, 44(1), 123-142.

Ersoy, Y. (2003). Teknoloji destekli matematik egitimi-1: Gelişmeler, politikalar ve stratejiler. Elementary Education Online, 2(1), 18-27.

Farmaki, V., \& Paschos, T. (2007). The interaction between intuitive and formal mathematical thinking: a case study. International Journal of Mathematical Education in Science and Technology, 38(3), 353-365.

Fischbein, E. (1999). Intuitions and schemata in mathematical reasoning. Educational Studies in Mathematics, $38(1-3), 11-50$.

Fujita, T., \& Jones, K. (2014). Reasoning-and-proving in geometry in school mathematics textbooks in Japan. International Journal of Educational Research, 64, 81-91.

Gal, I., Rothschild, K., \& Wagner, D. A. (1990, April). Statistical concepts and statistical reasoning in school children: Convergence or divergence? In annual meeting of the American Educational Research Association, Boston, MA.

Güler, H. K. (2013). Türk öğrencilerin PISA'da karşılaştıkları güçlüklerin analizi. Uludă̆ Üniversitesi Eğitim Fakültesi Dergisi, 26(2), 501-522.

Gürbüz, R., Toprak, Z., Yapıcı, H., \& Doğan, S. (2011). Subjects perceived as difficult in secondary mathematics curriculum and their reasons. University of Gaziantep Journal of Social Sciences, 10(4), 13111323.

Herbert, S., Vale, C., Bragg, L. A., Loong, E., \& Widjaja, W. (2015). A framework for primary teachers' perceptions of mathematical reasoning. International Journal of Educational Research, 74, 26-37.

Jonsson, B., Norqvist, M., Liljekvist, Y., \& Lithner, J. (2014). Learning mathematics through algorithmic and creative reasoning. The Journal of Mathematical Behavior, 36, 20-32.

Lithner, J. (2000). Mathematical reasoning and familiar procedures. International Journal of Mathematical Education in Science and Technology, 31(1), 83-95.

Lithner, J. (2003). Students' mathematical reasoning in university textbook exercises. Educational Studies in Mathematics, 52(1), 29-55.

Lithner, J. (2004). Mathematical reasoning in calculus textbook exercises. Journal of Mathematical Behavior, $23,405-427$. 
Lithner, J. (2008). A research framework for creative and imitative reasoning. Educational Studies in Mathematics, 67(3), 255-276.

Lobato, J., \& Siebert, D. (2002). Quantitative reasoning in a reconceived view of transfer. The Journal of Mathematical Behavior, 21(1), 87-116.

Konold, C., \& Pollatsek, A. (2002). Data analysis as the search for signals in noisy processes. Journal for Research in Mathematics Education, 33, 259- 289.

Kramarski, B. A., Mevarech, Z. R., \& Lieberman A. (2001). Effects of multilevel versus unilevel metacognitive training on mathematical reasoning. Journal of Educational Research, 94(5), 292-300.

Miles, M. B., \& Huberman, A. M. (1994). An Expanded Sourcebook: Qualitative Data Analysis (Second edition). Thousand Oaks, CA: SAGE Publications, Inc

Ministry of National Education [MoNE] (1998). Ilköğretim okulu matematik dersi öğretim programı: 1-8. sinıflar. İstanbul: Milli Eğitim Basımevi

Ministry of National Education [MoNE] (2009). Illköğretim matematik dersi 1-5. sinıflar ögretim programı. Ankara: T.C. Milli Eğitim Bakanlığı. Talim ve Terbiye Kurulu Başkanlığı. Retrieved November 11, 2020 , from http://talimterbiye.mebnet.net/Ogretim\%20Programlari/ilkokul/2010-2011/Matematik1-5.pdf

Ministry of National Education [MoNE] (2013). Ortaokul matematik dersi (5, 6, 7 ve 8. sinuflar) ögretim programı. Ankara: T.C. Milli Eğitim Bakanlığı. Talim ve Terbiye Kurulu Başkanlığı. Retrieved November 11, 2020, from http://talimterbiye.mebnet.net/Ogretim\%20Programlari/ortaokul/ana.html

Ministry of National Education [MoNE] (2015). Ilkokul matematik dersi (1, 2, 3 ve 4. sinıflar) ögretim programı. Ankara, T.C. Milli Eğitim Bakanlığı. Talim ve Terbiye Kurulu Başkanlığı. Retrieved November 11, 2020, from http://matematikogretimi.weebly.com/uploads/2/6/5/4/26548246/matematik1-4_prg.pdf

Ministry of National Education [MoNE] (2018a). Matematik dersi ögretim programı (ilkokul ve ortaokul 1,2,3,4,5,6,7 ve 8. sinıflar). Ankara, T.C. Milli Eğitim Bakanlığ1. Retrieved November 11, 2020, from http://mufredat.meb.gov.tr/Dosyalar/201813017165445-

MATEMAT\%C4\%B0K\%20\%C3\%96\%C4\%9ERET\%C4\%B0M\%20PROGRAMI\%202018v.pdf

Ministry of National Education [MoNE] (2018b). Ortä̈gretim matematik dersi (9, 10, 11 ve 12. sinfflar) ögretim programı. Ankara, T.C. Milli Eğitim Bakanlığı. Retrieved November 11, 2020, from http://mufredat.meb.gov.tr/Dosyalar/201821102727101OGM\%20MATEMAT\%C4\%B0K\%20PRG\%2020.01.2018.pdf

Merriam, S.B. (2009). Qualitative research: A guide to design and implementation: Revised and expanded from qualitative research and case study applications in education. (3rd ed.), Jossey-Bass, San Francisco, California

Mokros, J., \& Russell, S. J. (1995). Children's concept of average and representativeness. Journal for Research in Mathematics Education, 26, 20 - 39.

NCTM (National Council of Teachers of Mathematics) (2000). Principles and standards for school mathematics. Reston, VA. Retrieved November 24, 2019, from http://www.nctm.org/

NCTM (National Council of Teachers of Mathematics) (2009). Focus in high school mathematics: Reasoning and sense making. Reston, VA. Retrieved November 24, 2019, from http://www.nctm.org/

Patton, M. Q. (2002). Qualitative evaluation and research methods (Third ed.). Newbury Park, CA: Sage Publications.

Poçan, S., Yaşaroğlu, S., \& İlhan, A. (2017). Investigation of secondary 7th and 8th grade students' mathematical reasoning skills in terms of some variable. Journal of International Social Research, 10(52). 808-818.

Pollatsek, A., Lima, S. \& Well, A.D. (1981). Concept or computation: Students' understanding of the mean, Educational Studies in Mathematics, 12, 191-204.

Schoenfeld, A. (1991). On mathematics as sense-making: An informal attack on the unfortunate divorce of formal and informal mathematics. In J. Voss, D. Perkins \& J. Segal (Eds.), Informal reasoning and education (pp. 311-344). Hillsdale, NJ: Lawrence Erlbaum Associates.

Silver, E. A. (1997). Fostering creativity through instruction rich in mathematical problem solving and problem posing. ZDM - The International Journal on Mathematics Education, 29(3), 75-80.

Skemp, R. R. (1976). Relational understanding and instrumental understanding. Mathematics Teaching, 77(1), 20-26.

Thompson, P. W., Hatfield, N. J., Yoon, H., Joshua, S., \& Byerley, C. (2017). Covariational reasoning among US and South Korean secondary mathematics teachers. The Journal of Mathematical Behavior, 48, 95-111.

Toluk-Uçar, Z. \& Akdoğan, E. N. (2009). Middle school students' understanding of average. Elementary Education Online, 8(2), 391-400.

Umay, A. (2003). Mathematical reasoning ability. Hacettepe University Journal of Education, 24(24), $234-243$.

Umay, A., \& Kaf, Y. (2005). A study on flawed reasoning in mathematics. Hacettepe University Journal of Education, 28(28), 188-195.

Yeşildere, S., \& Türnüklü, E. B. (2007). Examination of students' mathematical thinking and reasoning processes. Ankara University, Journal of Faculty of Educational Sciences, 40(1), 181-213. 
Watson, M. \& Moritz, J. (2000). The longitudinal development of understanding of average. Mathematical Thinking and Learning, 2(1\&2), 11-50.

Watson, J., Chick, H., \& Callingham, R. (2014). Average: The juxtaposition of procedure and context. Mathematics Education Research Journal, 26(3), 477-502.

Wyndhamn, J., \& Säljö, R. (1997). Word problems and mathematical reasoning —a study of children's mastery of reference and meaning in textual realities. Learning and Instruction, 7(4), 361-382.

\section{Appendix. Average test}

1. a) Have you ever heard of the word "average" before? Where did you hear? What do you think it means?

b) "According to a study, there are an average of 32 students per class in Turkey." What do you think the word "average" means in this sentence?

c) How do you think this average (32 students per class) was obtained (calculated)? Can you give an example of how many people can be in some classes? Can you show how the researchers might have calculated the average from this?

2. Let's say you read a news article saying "According to TurkStat 2014 data, Turkey household size (number of people per household) is 3.6."

a) What does this sentence mean? Is it correct to express the number of people with a decimal number like 3.6, not a natural number like $1,2,3$ ?

b) Suppose that the average person per household in a 10 house apartment is 3.6. If there are 2 people in 3 rd household and 5 people in 5th household, how many people are there in the remaining 8 households?

3. When creating a team for a sports match, the following rules must be followed:

a) The average height of the team must be between 138 and $145 \mathrm{~cm}$.

b) 3 people must be selected to the team.

\begin{tabular}{cccccc}
\hline Student & Ayça & Burak & Ceren & Demet & Fırat \\
\hline Height $(\mathbf{c m})$ & 140 & 150 & 130 & 120 & 180 \\
\hline
\end{tabular}

4. Murat notices that there are different numbers of candies in each of the sugar packs he is buying from the store. He decides to count how many sugar there are in the packages and decides to count. To do this, he buys a number of sugar packages from the store and counts the candies in each pack, creating the chart below (Figure $1)$.

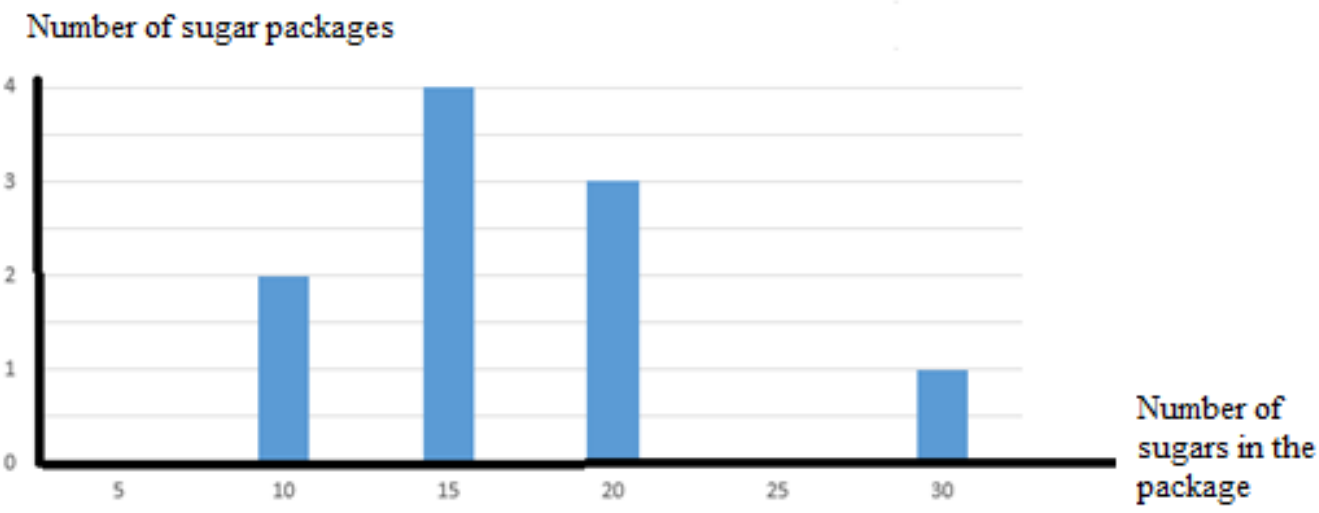

Figure 1. Chart of the number of sugars in the packs

a) What is the average of the number of sugar in the packages he bought?

b) What does the result you found mean?

c) Murat draws another column in one of the spaces in the chart, saying that the average increases when he opens 1 more package. Where could he draw this column? 
5. Three sticks $3 \mathrm{~cm}, 5 \mathrm{~cm}$ and $13 \mathrm{~cm}$ in length were placed in front of the student as in Figure 2 . In addition to these three sticks, four of each of red labeled sticks of $6 \mathrm{~cm}$, blue labeled sticks of $7 \mathrm{~cm}$ and black labeled sticks of $8 \mathrm{~cm}$ were provided. The students were not informed about the length of any of these sticks, and they were asked to use the colored sticks as they wish, and the following question was asked: "Which of these three kind of sticks is the average of the length of these three sticks?"

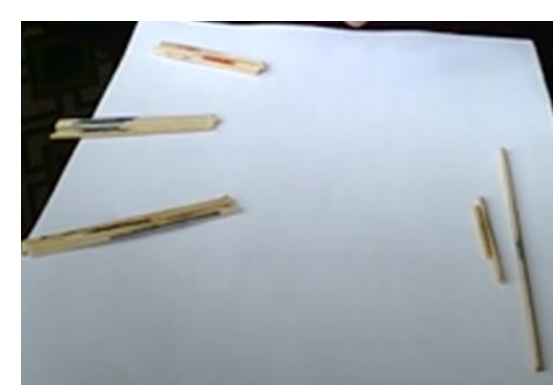

Figure 2. Sticks used in the 5th question of the research 